\title{
POLA INTERAKSI SOSIAL ANTAR PEDAGANG BUKU DI PASAR WILIS KOTA MALANG
}

\author{
Syamrotul Mu' Arofah \\ Program Studi Pendidikan Ilmu Pengetahuan Sosial, Universitas Negeri Malang \\ Email:arofahsm07@gmail.com
}

\begin{abstract}
Abstrak: Penelitian ini bertujuan untuk mengetahui karakteristik serta pola interaksi sosial antar pedagang di pasar Wilis, sekaligus untuk mengetahui faktor pendukung dan penghambat interaksi tersebut. Penelitian ini merupakan penelitian kualitatif. Teknik yang digunakan untuk mengumpulkan data dalam penelitian ini adalah observasi, wawancara, dan dokumentasi. Analisis data dalam penelitian ini mengacu pada model analisis interaktif yang diajukan Miles dan Huberman dengan tahapan: reduksi data, penyajian data, dan verifikasi data. Berdasarkan hasil penelitian, pola interaksi sosial antar pedagang yang terlihat berupa kerjasama, persaingan, konflik, dan akomodasi. Kerjasama perdagangan tersebut terjadi secara spontan baik dalam kegiatan sosial dan juga ekonomi. Sedangkan bentuk persaingannya adalah atas dasar persaingan ekonomi. Konflik yang ada juga bersifat pribadi dan juga tidak sampai anarkis. Akomodasi yang dilakukan oleh para pedagang juga tidak sampai pada pihak ke tiga. Faktor yang mendorong pola interaksi sosial antar pedagang di wilayah Ampel adalah (1) adanya tujuan; (2) dan situasi sosial. Sedangkan faktor yang menghambatnya adalah (1) hambatan sosiologi (2) hambatan antropologis (3) hambatan psikologis, dan (4) hambatan ekologis.
\end{abstract}

Kata Kunci: interaksi sosial, pedagang.

Manusia sebagai mahluk sosial akan saling menjalin hubungan atau suatu interaksi sosial dengan orang lain dalam kehidupan sehari-hari. Interaksi tersebut dapat berupa interaksi di bidang sosial, ekonomi, politik, dan sebagainya. Interaksi yang sering dilakukan oleh manusia salah satunya dalam bidang ekonomi, yaitu di pasar buku Wilis kota Malang. Pasar buku Wilis dimanfaatkan oleh masyarakat untuk dijadikan sebagai peluang bagi pedagang buku.

Keberadaan pasar buku Wilis berawal pada tahun 2003 yang merupakan salah satu program pemerintah untuk menjadikan pedagang yang non formal menjadi formal. Dahulu sebelum direlokasikan di pasar buku Wilis, para pedagang berjualan di daerah Splendid. Berdasarkan data dari Badan Pusat Statistik (BPS) tahun 2014 tentang jumlah pedagang dan jumlah tempat usaha menurut pasar dan kecamatan, bahwa pasar buku Wilis terdapat 68 unit kios dan 60 pedagang yang bersandingan dan sama-sama menjual buku. Buku yang disediakan ribuan jenis mulai dari buku bacaan, novel fiksi ataupun nonfiksi, buku kedokteran dan juga menjual buku-buku bagi perguruan tinggi negeri.

Pedagang buku yang berada di pasar Wilis memiliki karakteristik yang berbeda. Hal ini dapat dilihat dengan banyaknya pedagang yang rata-rata berusia tua dan sedikit pedagang yang berusia muda. Para pedagang juga ada yang berasal dari masyarakat sekitar, namun ada juga dari kalangan masyarakat pendatang. Banyaknya jumlah pedagang buku yang berada di pasar Wilis, pasti memiliki karakteristik yang berbeda. Hal tersebut tentunya akan menciptakan suatu interaksi sosial maupun hubungan kerja antara satu dengan yang lainnya. Apabila dua orang bertemu, maka interaksi sosial dapat terjadi pada saat itu, mereka saling menegur,berjabat tangan,saling berbicara, dan bahkan saling berkelahi (Santosa,2017:50).

Interaksi sosial antar pedagang buku juga bisa dilihat dalam kegiatan sosial, hal tersebut terjadi ketika salah satu pedagang yang tidak menjual buku yang dicari oleh pembeli, maka pedagang tersebut merujuk untuk membeli ke pedagang lain. Interaksi sosial yang terjadi, membuat satu pedagang dengan pedagang lainnya dapat menghasilkan 
suatu pola interaksi sosial. Pola tersebut dapat bersifat negatif maupun positif. Pola yang bersifat positif dalam kegiatan perdagangan buku di pasar Wilis, adalah kerja sama. Sedangkan pola yang bersifat negatif dapat berupa konflik, hal ini dapat terjadi akibat adanya persaingan antar pedagang buku selama berdagang yang tidak mungkin bisa dihindarkan.Suatu interkasi sosial antar pedagang buku di pasar Wilis, tidaklah lepas dari adanya suatu faktor. Faktor-faktor dari interkasi dapat menentukan suatu pola.

Alasan peneliti tertarik dengan subyek penelitian ini karena, pertama dengan banyaknya jumlah pedagang buku dipasar Wilis, peneliti ingin menggambarkan bagaimana pola interaksi yang terjadi serta karkteristik yang ada. Kedua, penelitian yang berfokus pada subjek kajian pedagang di pasar buku Wilis ini masih jarang. Ketiga, karena peneliti telah mengenal salah satu pedagang di pasar buku Wilis.

\section{METODE}

Penelitian ini menggunakan pendekatan kualitatif Karaktersitik penelitian kualitatif ini dilakukan pada kondisi yang alamiah, sebagai lawannya adalah eksperimen, langsung ke sumber data dan peneliti adalah instrumen kunci (Sugiyono,2016:13). Jenis penelitian deskriptif yaitu jenis penelitian yang bertujuan untuk mengetahui keadaan apa dan bagaimana, seberapa banyak, seberapa jauh status tentang fokus yang diteliti. Penelitian ini dilakukan di pasar buku Wilis. Data dan sumber data dalam penelitian ada dua, yaitu data primer yang merupakan data yang didapat dari pertanyaan yang tertulis dengan angket atau lisan dengan cara wawancara (Sarwono,2012:16) dan sumber data dalam penelitian ini terdiri dari 8 informan kunci dan 2 informan pendukung. Data sekunder ini lebih sering dikenal dengan data yang menggunakan studi kepustakaan (Sarwono,2012:17).

Teknik yang digunakan untuk mengumpulkan data dalam penelitian ini adalah: (1) Observasi. Observasi merupakan teknik pengumpulan data dengan jalan mengadakan pengamatan langsung terhadap kegiatan yang sedang berlangsung (Sugiyono, 2009:310). (2) Wawancara dilakukan dengan wawancara agar dapat mengumpulkan data secara lengkap dan terperinci. (3) Dokumentasi yang berarti mengumpulkan dokumen dan data-data yang diperlukan dalam permasalahan penelitian lalu ditelaah secara intens sehingga dapat mendukung dan menambah kepercayaan dan pembuktian suatu kejadian. Dokumen dibagi atas dokumen pribadi dan dokumen resmi (Satori,2011: 149).

Analisis data dalam penelitian ini mengacu pada model analisis interaktif yang diajukan Huberman dan Miles . Langkah pertama dalam model analisis interaktif adalah reduksi data (data reduction).. Reduksi data dalam penelitian ini dilakukan setelah diperoleh data dari hasil observasi, wawancara, dan dokumentasi, kemudian dipilih data-data pokok dan difokuskan pada hal-hal yang penting, sehingga data penelitian menjadi lebih jelas dan sistematis. Langkah kedua dalam model analisis interaktif adalah penyajian data (data display). Dalam penelitian ini, data disajikan berupa teks naratif yang mendeskripsikan mengenai subjek penelitian, yakni menggambarkan bagaimana pola interaksi antar pedagang di pasar Wilis. Langkah ketiga dalam model analisis interaktif adalah verifikasi data (data verification). Dalam penelitian ini, verifikasi data dilakukan dengan menghubungkan data dengan teori aksi sosial Parsons untuk penarikan simpulan.

\section{HASIL DAN PEMBAHASAN Karakteristik Pedagang di Wilis}

Pedagang di pasar, sebagian besar di dominasi oleh laki-laki, di karenakan, para laki-laki mempunyai tujuan tertentu yakni berdagang untuk membantu dan menafkahi keluarga di rumah. Tidak hanya itu, para laki-laki juga melakukan berdagang buku, sebagai sampingan pada saat menjelang pagi hingga sore hari. Sementara pedagang perempuan juga ada, namun masih terbilang sedikit. Jenis 
kelamin antara laki-laki dan perempuan tentu berbeda dalam hal jual menjual dari berbagai macam kebutuhan (Munir,2014:25). Hal ini dikarenakan seorang laki-laki lebih mampu menjual buku di setiap harinya, daripada seorang perempuan yang lebih repot dalam mengurus anaknya ketika berdagang. Para pedagang buku, baik laki-laki atau perempuan banyak yang berusia 26 hingga 60 tahun dan masih terbilang produktif

Buku yang di jual oleh pedagang juga sangat beragam. Jenis buku tersbut mencakup jenis buku refrensi, yaitu buku yang digunakan sebagai rujukan yang berisi informasi singkat dan padat bagi sekolah dasar ataupun perguruan tinggi. Misalnya saja buku tematik, buku pendidikan, buku kesehatan, buku ekonomi, buku teknik dan juga buku tentang pendidikan agama islam (PAI). Pemilihan jenis buku tersebut, berdasarkan atas permintaan dari pembeli atau pelanggan. Meskipun para pedagang lebih banyak menjual buku refrensi, namun buku jenis yang lainnya pun juga ada. Buku tersebut adalah buku acuan seperti hal nya buku tentang resep masakan, tuntunan sholat, dan cara budidaya ikan (Alwi,2015:491)

Pendidikan menjadi hal yang sangat penting bagi setiap orang. Pendidikan terakhir para pedagang ratarata masih tergolong sedang, yakni tamatan dari SMP - SMA dan bahkan ada yang tidak menempuh bangku sekolah. Hanya sebagian kecil saja pedagang yang menempuh pendidikan hingga sarjana, dengan pendidikan seseorang bisa berkompetisi dalam suatu pasar kerja. Pedagang yang menempuh pendidikan lebih tinggi, menerapakan penjualan buku yang up to date dan juga strategi dalam memikat para konsumen yang sudah menjadi budaya pasar. Berbeda dengan pedagang yang menempuh pendidikan sedagang yang hanya mengandalkan satu jenis buku saja dan kurangnya dalam penggunaan media online.

Asal tempat tinggal para pedagang pun juga beragam, ada yang dari
Makasar, Tuban, Gersik, dan Surabaya. Umumnya para pedagang berasal dari kota Malang. Untuk para pedagang yang dari luar daerah, saat ini sudah menetap dan bahkan menjadi warga Malang. Perpindahan pedagang dari kota asal, juga memiliki tujuan tertentu yakni untuk melakukan pekerjaan yang lebih baik lagi daripada sebelumnya (Mantra,2014:10). Asal para pedagang juga berpengaruh terhadap lama berjualan. Ada pedagang yang berjualan selama 15 tahun yakni sejak berdirinya pasar Wilis, dan sisanya selama $10-13$ tahun.

Berkaitan dengan modal dan juga pendapatan pedagang terdapat 2 jenis modal. Pertama, modal milik sendiri yang berarti adalah modal yang sumbernya dari perorangan dan hasilnya telah menjadi sumber pendapatan bagi pemilik modal dan bahkan menjadi tabungan di masa depan. Kedua, modal milik campuran yang berarti adalah modal yang berasal dari campuran uang pribadi dan juga milik orang lain (Juliasty,2009: 6-13). Namun modal campuran, hanya sebagian pedagang saja dari orang tua pedagang dan juga campur tangan dari pihak penerbit.

Pendapatan yang dimiliki oleh seorang pedagang, juga tidak menentu dalam artian masih tergolong relatif. Hal ini, karena di pengaruhi oleh keadaan ramai dan sepi nya pasar oleh pembeli (Marsono,2018:33). Pada saat memasuki ramai pembeli yakni pada bulan ajaran baru, para pedagang bisa mendapatkan penghasilan sekitar Rp.900.000 Rp.9.000.000 per tiap bulan. Apabila pasar memasuki bulan sepi yakni pada saat musim hujan, musim awal tahun, pedagang hanya mendapatkan penghasilan sekitar Rp. 20.000 Rp.500.000 per tiap bulan. Besar kecilnya dari penghasilan tersebut, para pedagang tetap merasa cukup untuk memenuhi kebutuhan sehari-hari, karena hanya di potong sebesar Rp.50.000 untuk iuran pasar dan juga uang makan.

Pola Interaksi Sosial antar Pedagang Buku Wilis 
Kesamaan jenis dagangan dan tempat, menjadi seringnya pedagang untuk melakukan interaksi sosial. Hubungan tersebut berupa kontak sosial, dapat terlihat pada saat pedagang melakukan tatap muka dan berjabat tangan pada saat pagi hari waktu buka pasar antar sesama pedagang. Komunikasi juga terjadi, tidak pada saat tatap muka, namun juga melalui via whatssap yaitu adanya grup khusus bagi para pedagang buku. Setiap perilaku pedagang dalam melakukan hubungan interaksi, dapat dinyatakan kedalam aksi sosial. Bahwasannya aksi itu berkaitan dengan invidu, sebagai aktor yang melakukan interaksi sosial dengan adanya tujuan. Tujuan para pedagang melakukan interaksi, tidak lain untuk memajukan pasar Wilis agar sesama pedagang terlihat lebih rukun. Interaksi juga sudah di anggap sebagai kebiasaan para pedagang dalam kehidupan seharihari di pasar Wilis.

Interaksi yang berlangsung secara terus menerus di lingkup para pedagang, menimbulkan terbentukny perkumpulan atau organisasi. Kelompok pedagang disebut juga paguyuban. Paguyuban merupakan sebuah perkumpulan yang bersifat kekeluargaan, yang didirikan oleh orang-orang yang sepaham atau sedarah untuk membina persatuan serta kerukunan yang tercipta di antara para anggotanya (Nurjayanti,2013:9). Organisasi ini bernama paguyuban pedagang pasar Wilis Malang atau lebih disingkat dengan P3BWM.

Pola interaksi sosial antar pedagang yang terlihat cukup banyak, sesuai dengan tujuan dan perilaku. Pertama, adanya suatu kerja sama yang akan terbentuk ketika individu dengan individu lain memiliki kepentingankepentingan dengan pencapaian tujuan yang sama (Santosa,2017:20). Kerja sama dalam hal perdagangan buku di pasar, termasuk ke dalam kerja sama spontan artinya tanpa adanya suatu perintah terlebih dahulu. Hal ini dilakukan oleh pedagang pada saat saling tukar menukar barang dagangan antar pedagang. Apabila buku yang di cari oleh pembeli tidak ada, maka pedagang bisa mengambilkan atau menjualkan buku dari kios lain ke pada konsumen.

Para pedagang, juga melakukan kerja sama dalam kegiatan sosial, namun dengan waktu-waktu tertentu. Misalnya, dalam perayaan maulid Nabi di mana para pedagang berdiskusi tentang acara. Tidak hanya dalam kegiatan tersebut, kerja sama juga dilakukan dalam kegiatan penggalangan dana sosial untuk korban Palu, dengan menyumbangkan beberapa buku dan uang. Kerja sama pedagang juga terkihat pada saat melakukan kerja bakti dan slametan (barikan) di bulan-bulan tertentu yakni bulan Agustus dan bulan akan memasuki puasa ramadhan.

Selain kerja sama, pola interaksi sosial yang terlihat adalah persaingan (competition). Persaingan pedagang yang paling dominan adalah persaingan ekonomi, dimana satu pedagang dengan pedagang lain saling bersaing untuk menarik konsumen atau pembeli sebanyak mungkin. Persaingan juga bisa di rasakan oleh pedagang, ketika pedagang lain berkunjung ke kios yang lain namun juga melihat-lihat buku yang laris di jual belikan. Hal tersebut pedagang yang menjual nya merasa tersaingi, dan bahkan pedagang yang lain bisa menjualnya lebih murah. Persaingan ekonomi yang terjadi, di pasar Wilis tebilang masih dalam taraf persaingan sehat. Hal ini dibuktikan dari tidak adanya konflik antar pedagang di kawasan itu.

Konflik yang terjadi antar pedagang tidak sampai pada titik anarkis dan juga menimbulkan kekerasan. Suatu persaingan yang ada dapat menimbulkan suatu konflik yang merupakan segala macam interaksi pertentangan antara dua atau lebih pihak (Muharto,2016:61). Konflik tersebut hanya bersifat kepada perasaan setiap individu, artinya pada saat pedagang mencoba untuk merebut konsumen atau pembeli dari pedagang yang lain, maka pedagang tersebut akan merasa marah dan merasa kecewa namun masih dalam hal wajar. Tidak hanya itu saja pedagang juga merasa adanya 
kecemburuan sosial dengan pedagang yang lain, apabila pedagang di sebelah lebih ramai padahal yang di jual belikan buku dengan jenis yang sama.

Konflik yang timbul dapat memicu adanya akomodasi. Akomodasi merupakan interaksi sosial yang melibatkan dua atau lebih individu atau kelompok yang berusaha tidak saling mengganggu dengan cara mencegah, mengurangi, atau menghentikan ketegangan yang timbul atau yang sudah ada. Persaingan dan juga konflik yang ada, tidak sampai pada tahap peleraian dengan melibatkan beberapa pihak. Antar pedagang lebih ke dalam hubungan yang baik-baik saja, serta mengatasi permasalahan tidak sampai pada tindak lanjut yang lebih. Misalnya permasalahan dalam persaingan menarik konsumen, pedagang hanya bisa pasrah dan tidak sampai mengejek pedagang yang lain.

\section{Faktor Pendorong dan Penghamabat dalam Interaksi sosial antar Pedagang Buku Wilis}

Interaksi sosial antar pedagang tidak akan terlepas dari suatu faktor pendorong. Faktor pendorong berarti faktor yang mendukung terjalinnya suatu interaksi sosial baik berasal dari dalam diri seseorang atau situasi yang ada (Murdiyatmoko,2007:10). Faktor yang dimaksudkan adalah situasi sosial dimana para pedagang harus dapat menyusaikan diri terhadap apa yang di hadapi. Seperti yang telah diketahui bahwa pasar merupakan tempat yang ramai dan juga tempat bertemunya para penjual dan juga pembeli. Hal ini kemudian menjadi salah satu pendorong terjadinya interaksi sosial antara pedagang dan pembeli.

Adanya tujuan pribadi bisa dijadikan faktor pendorong dalam proses interaksi sosial. Tujuan pribadi tersebut adalah untuk menjalin hubungan yang lebih erat khususnya antar sesama pedagang buku, dan juga adanya hubungan serta rasa kekeluargaan sehingga dapat memberikan suatu kenyamanan satu sama lain. Penafsiran situasi menjadikan faktor pendorong bagi para pedagang untuk melakukan interaksi. Menafsirkan situasi, artinya bisa melihat dan juga memaknai terhadap situasi yang di hadapi atau yang berada disekitarnya (Adeney,2002:315). Pada saat keadaan pasar sepi pembeli, pedagang akan lebih sering dan bahkan banyak untuk ber interaksi sosial satu sama lain. Ketika pasar sepi, pedagang ada yang bermain catur khususnya kalangan Bapak-Bapak, dan ada yang mengadakan rujakan dengan sesama pedagang.

Faktor penghambat juga terdapat dalam suatu hal interaksi sosial antar pedagang. Faktor penghambat merupakan faktor yang dapat mencegah suatu interaksi sosial yang terjadi antar individu dengan individu lain ataupun kelompok (Santosa,2017:13). Antaranya hambatan sosiologis yang lebih berkaitan dengan perbedaan status, tingkat pendidikan, tingkat kekayaan dan sebagainya. Salah satu pedagang merasa tidak adanya kenyamanan dalam melakukan interaksi, dikarenakan tingkat pendidikan yang lebih rendah dari pedagang yang lain. Sulitnya berinteraki sosial yang di rasakan adalah susahnya ber diskusi dengan pedagang yang lain, karena minimnya pemahaman tentang kehidupan sekolah yang di rasakan oleh pedagang.

Hambatan antropologis, merupakan hambatan yang berkaitan dengan perbedaan ras dan suku bangsa. Pedagang yang berasal dari Makasar, merasa sulitnya melakukan interaksi sosial dengan para pedagang lain pada saat mula berjualan. Hal ini di pengaruhi oleh perbedaan bahasa dengan pedagang lain yang lebih dominan dengan orang Jawa yang khas akan kata-kata opo,sopo, nak endi.

Keadaan psikologis pedagang yang berkaitan dengan proses-proses kejiwaan atau mental dari orang yang melakukan interaksi sosial, bisa menjadi penghambat dalam interaksi. Ketika salah satu pedagang merasakan bahwa pedagang yang lain sedang menunjukkan raut wajah kecewa, dan sedih maka 
mereka hendak saling berinteraksi. Hal ini dilakukan karena tidak adanya rasa kenyamanan, sehingga interaksi sosial tidak terjalin sempurna.

Hambatan lain, yaitu berkaitan dengan ekologis atau dari lingkungan sekitar pasar Wilis, berupa kebisingan lalu lintas di depan pasar. Para pedagang menjadi merasa terganggu dengan

\section{KESIMPULAN DAN SARAN}

Karakteristik pedagang di pasar Wilis didasarkan atas jenis kelamin, jenis buku, pendidikan terakhir pedagang, asal pedagang, dan modal serta pendapatan pedagang. Pedagang Wilis lebih di dominan oleh kaum laki-laki dibandingkan dengan kaum perempuan. Jika di persentasikan adalah $70 \%$ pedagang kalangan laki-laki dan 30\% kalangan perempuan. Jenis buku yang di jual belikan oleh pedagang adalah berjenis buku refrensi bagi kalangan anak sekolah dasar hingga perguruan tinggi. Pendidikan terakhir pedagang sangat beragam di mulai dari tingkatkan SMP,SMA, Strata 1 (S1) atau bahkan ada yang tidak sekolah. Asal pedagang juga lebih minim yang dari luar kota Malang, namun masih ada beberapa pedagang yang berasal dari luar dan untuk saat ini sudah menetap dan menjadi warga Malang.

Modal serta pendapatan setiap pedagang berbeda-beda, hal ini karena didasarkan pada jenis buku yang di jual oleh pedagang. Modal pedagang juga sebagian ada yang milik sendiri dan dari milik campuran, artinya adanya campur mempererat tali persaudaraan. Ketiga, penafsiran situasi sosial yang di hadapi berarti makna atas situasi yang ada di sekitar pedagang, yakni pada saat pasar sepi oleh pengunjung.

Faktor penghambat juga menjadikan salah satu dari penghambatnya interaksi sosial, yaitu hambatan sosiologis yang berhubungan dengan perbedaan ras serta tingkat pendidikan seorang pedagang. Pedagang yang lebih merasa tidak nyaman pada saat berinteraksi dengan pedagang yang lain. Hambatan antropologis yang ramainya jalan, sehingga ketika melakukan interaksi sosial maka pedagang akan lebih mengeraskan suara dan juga ada yang bahkan sampai teriakteriak. Hambatan ekologis juga dirasakan, apabila ada suara ricuh dari pedagang yang lain. Maka dalam keadaan seperti itu, pedagang yang berinteraksi akan diam terlebih dahulu.

tangan dari orang tua atau dari penerbit buku.

Adanya suatu paguyuban yaitu P3BWM sebagai salah satu sarana dalam berinteraksi di beragai macam kegiatan yaitu kegiatan sosial yang berbasis keagamanan dan juga berbasis sumbangan donasi terhadap yang membutuhkan. Kegiatan ekonomi, juga di lakukan setiap hari oleh pedagang dan di realisasikan dengan adanya kerja sama sesama pedagang. Persaingan yang terjadi juga di bilang masih sehat dan tidak sampai pada menimbulkan konflik. Konflik yang ada cuman hanya berasal dari pribadi pedagang, yakni pada saat merasa kecewa dengan pedagang lain.

Faktor-faktor yang dapat mempengaruhi interaksi ada dua, yaitu faktor pendorong yang pertama adanya situasi sosial yang pedagang berada di pasar dan masih dalam lingkup satu atap yang akan melakukan interaksi baik sesama pedagang atau dengan para pembeli. Kedua, Tujuan pribadi dari masing-masing pedagang yang melakukan interaksi sosial yang ingin melakukan interaksi untuk

bekaitan dengan perbedaan ras dan juga bahasa. Hal ini para pedagang yang tidak bisa memahami bahasa pedagang yang dari Jawa dan Madura, akan mengalami kesulitan tertentu pada saat melakukan interaksi. Hambatan psikologis, yaitu hambatan yang berhubungan dengan keadaan jiwa orang yang melakukan interaksi, dimana keadaan tersebut berupa marah, sedih, kecewa. Tapi para pedagang lain juga merasa tidak nyaman. Hambatan ekologis, yaitu yang berkaitan dengan lingkungan sekitar pedagang, dimana pada saat melakukan interaksi 
satu sama lain terganggu dengan bisingnya jalan raya dan juga pedagang yang lain.

Peneliti menyarankan kepada peneliti sleanjutnya, untuk meneliti hal yang lain yakni mengenai Interaksionisme simbolik antar pedagang dengan pembeli buku di Wilis, Meneliti bagaimana perubahan omzet atau pendapatan pedagang buku dari cetak ke berbasis online., Peran lembaga paguyuban pedagang pasar buku Wilis Malang (P3BWM) dalam kegiatan sosial pedagang Wilis

\section{DAFTAR PUSTAKA}

Alwi,Hasan.2015.Jenis-Jenis

Buku.Jakarta:Balai Pustaka

Badan Pusat Statistik (BPS). 2014. Jumlah Pedagang dan Jumlah Tempat Usaha Menurut Pasar dan Kecamatan.(Online),(www.bps.go.id), di akses 08 September 2018.

Juliasty,Sari.2009.Cerdas Mendapatkan dan Mengelola Modal Usaha.Jakarta:Balai Pustaka.

Mantra, Ida Bagoes. 2014. Demografi Umum. Pustaka Pelajar. Yogyakarta:Pustaka Belajar

Marsono,dkk.2018.Dampak Pariwisata Religi Kawasan Masjid Sunan Kudus terhadap Ekonomi,Lingkungan dan Sosial Budaya. Yogyakarta: Gadjah Mada University Press

Muharto.2016.Fitrahlogi:Pendekatan Terpadu Menembus Akar Perdamaian dan Konflik Sosial.Yogyakarta:Deepublish

Murdiyatmoko,Juna.2007.Sosiologi Memahami dan Mengkaji Masyarakat.Bandung:Grafindo Meida Pratama

Munir, R.2014.Aspek Demografi Tenaga Kerja.Jakarta:Akademik Pressindo

Nurjayanti,Siti.2013. Peran Paguyuban Sangkan Paraning Dumadi Terhadap Perubahan Perilaku Ekonomi Komunitas Samin (Studi Kasus Di Desa Klopoduwur Kecamatan Banjarejo Kabupaten Blora). Jurnal Sosiologi, 2 (10). Dari https://lib.unnes.ac.id/18567/1/3401409 045.pdf
Untuk Pedagang untuk kedepannya sebaiknya juga lebih melibatkan para pengelola pasar dalam berbagai macam kegiatan yang ada baik dalam pemberian dana, sumbangan atau juga yang lain. Para pedagang juga hendaknya lebih erat lagi dalam melakukan interaksi sosial dengan para pengelola. Hal ini

di lakukan karena demi mencapai visi dan misi pasar Wilis.

Santosa,Slamet.2017.Dinamika

Kelompok.Jakarta:Bumi Aksara.

Sarwono,Jonathan.2012.Metode Penelitian Kuantitatif dan Kualitatif.Yogyakarta:Graha Ilmu.

Satori.Djam'an.2011.Metode Penelitian Kualitatif. Bandung: Alfabeta

Sugiyono. 2016. Metode Penelitian Kuantitatif, Kualitatif dan R\&D. Bandung:CV. Alfabeta. 